\title{
Menomonee Valley Redevelopment and Community Park Methods
}

\section{Firm Liaisons:}

Greg Dorolek

Principal

Wenk Associates

Amber Stevens

Marketing Director

Wenk Associates

This case study was produced in 2010 as part of the Landscape Architecture Foundation's Landscape Performance Series pilot. LAF staff worked with representatives of firms to document the project and its environmental, social, and economic benefits.

To cite:

Landscape Architecture Foundation. "Menomonee Valley Redevelopment and Community Park Methods." Landscape Performance Series. Landscape Architecture Foundation, 2010. https://doi.org/10.31353/cs1431

The full case study can be found at: https://landscapeperformance.org/case-studybriefs/menomonee-valley-redevelopment 


\section{Menomonee Valley Redevelopment and Community Park Methodology for Landscape Performance Benefits}

- Increased developer yield (usable land) by 10 to $12 \%$ over conventional development by clustering development sites and consolidating stormwater management.

The consolidated stormwater treatment model yields an estimated $10-12 \%$ more usable land for developers. This assumes that in a conventional development, each site would be designed with a detention pond in order to meet the City requirement to manage stormwater for the 100-year event flood. Detention ponds are commonly located in the back corners of sites and surrounded by fences, making this land unusable for buildings or other site amenities. The following diagram was created to perform the land area calculations:

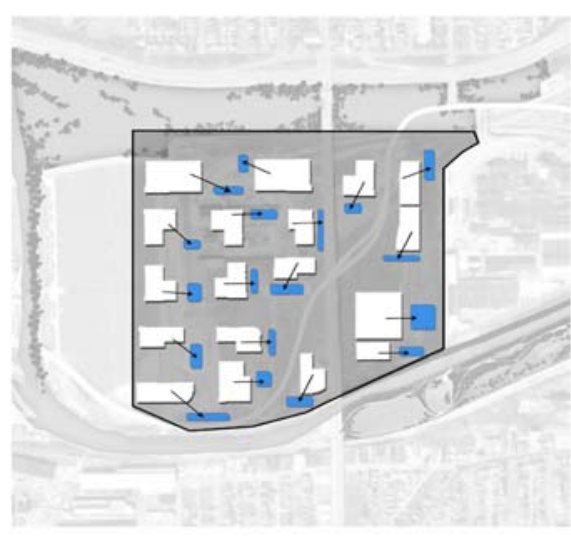

In a conventional development, each site would have its own detention pond.

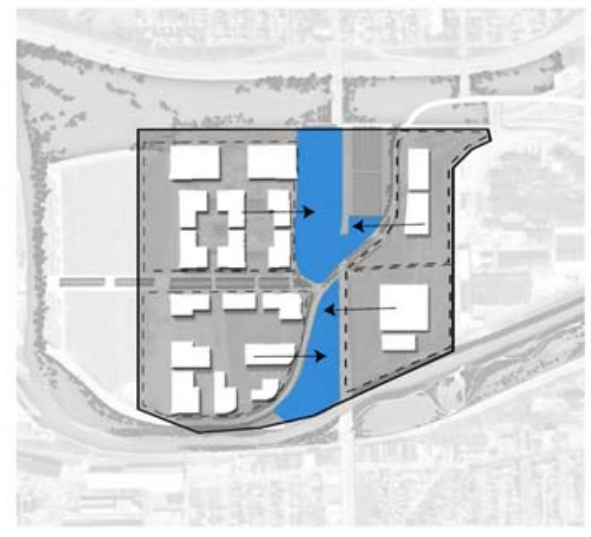

By consolidating stormwater management, the developable land on each site increases.

- Eliminates need for irrigation by using drought-tolerant native plants.

Figure from design, plans and construction documents.

- Manages 100-year flood volumes for an over 100-acre basin while improving water quality.

Figure from design, plans, and construction documents.

- Creates public access to the Menomonee River and over 60 acres of park/open space in an area that had been off-limits to the public for $50+$ years.

Figure from design, plans, and construction documents.

- Catalyzed the use of the Menomonee River Valley as an outdoor science laboratory, which receives 10,000 student visits annually.

Estimate from Urban Ecology Center as told by Laura Bray, Executive Director of Menomonee Valley Partners, Inc. on March 8, 2010.

- Added 3 pedestrian/bicycle bridges and 7 miles of regional bike and pedestrian trails, linking greater Milwaukee and neighborhoods to the park, river, and valley.

Figure from design, plans, and construction documents. 
- Increased development site property values by 1,400\% between 2002 and 2009.

Based on figures from Laura Bray, Executive Director of Menomonee Valley Partners, Inc. on March 8, 2010. In 2002, the 60 acres of redevelopment land assessed at \$1.2 million. In 2009, this same land was assessed at \$18 million.

- Created 2,000 new jobs by 2006, with 5,000 new jobs estimated to be created by 2015.

Estimate from Laura Bray, Executive Director of Menomonee Valley Partners, Inc. on March 8, 2010.

- Generates over $\$ 1$ million in annual City property tax revenues.

Figure from Laura Bray, Executive Director of Menomonee Valley Partners, Inc. on March 8, 2010. 